\title{
A Vulnerabilidade e a Proteção dos mais Fracos No MERCOSUL
}

\section{Marília Zanchet}

INTRODUČÃO. I. A NOÇÃO DE VULNERABILIDADE NO ÂMBITO DO MERCoSUL. A) Construção do Conceito de Vulnerabilidade: Análise da Doutrina do Mercosul. B) Declatação da ONU em Defesa dos Vulneráveis e sua Tutela nas Constituições Democráticas dos Países do Mercosul. II. A PROTEÇÃO DOS MAIS FRACOS NO ÂMBITO DO MERCOSUL . A) As Leis de Proteção dos Vulneráveis nos Ordenamentos Jurídicos dos Países do Mercosul: Comparativo das Leis de Defesa do Consumidor. B) Os Acordos Regionais, a Noção de Vulnerabilidade e a Proteção da Parte da mais Fraca no Mercosul. CONCLUSÃO. BIBLIOGRAFIA.

\section{INTRODUÇÃO}

A vulnerabilidade está e sempre esteve presente na sociedade. Dependendo-se do ângulo através do qual se observa, constantemente haverá pessoas que necessitam de maior proteção que outras, que por alguma tazão não conseguem se desenvolver da mesma maneira, dentro de determinados padrões. Assim, as sociedades, ao longo de seu processo de evolução, vão produzindo seus sujeitos vulneráveis. $\mathrm{Na}$ atualidade, hoje, podem-se citar inúmeros exemplos de vulneráveis que o Direito se ocupa em proteger, tais como crianças, idosos, trabalhadores, homossexuais, negros, mulheres, deficientes físicos, etc. No presente trabalho, contudo, o foco da análise da vulnerabilidade está no consumidor.

Embora nem sempre tenha apresentado a mesma denominação, a figura hoje conhecida como consumidor já pode ser encontrada em Roma, considerando-se que nas relações entre credor e devedor, já se previam formas de proteção ao contratante 
mais fraco. Além disso, segundo um dos relatores da Lei de Defesa do Consumidor Brasileira, a vulnerabilidade representa peça fundamental no mosaico jurídico que denominamos Direito do Consumidor, apresentando-se como ponto de partida de toda a teoria geral dessa nova disciplina jurídica. O conhecimento da vulnerabilidade, pois, é pressuposto para o próprio conhecimento do direito do consumidor e para a aplicação de qualquer lei que se proponha a salvaguardá-lo².

Somados a isso, há a realidade e a necessidade da inregração regional dos povos sulamericanos, através, dentre outros caminhos, do Mercosul. Dessa forma, o presente trabalho busca, num primeiro momento, construir um conceito de vulnerabilidade a partir da doutrina oriunda dos países componentes do Mercosul. Procura, também, analisar a forma como tais países, internamente e em nível tegional, têm buscado proteger os mais fracos. Dessa forma, então, se construirá uma noção de vulnerabilidade para os países do Mercosul, bem como se analisará a forma como esse conceito chega às Constituições Democráticas dos paises do Mercosul. Nesse sentido, se verá, de um lado, a grande importância das Nações Unidas na adoção de mecanismos de tutela dos mais fracos pelos países do Mercosul. Será possivel perceber, ainda, a crucial importância da democracia nesses países para que se pudessem adotar os mecanismos de tutela.

Num segundo momento, de forma mais prática, serão analisadas as leis de defesa do consumidor dos quatro países do mercosul e a forma encontrada por cada país para a tutela da vulnerabilidade. Por fim, serão verificados os Acordos assinados no âmbito do Mercosul que mencionam o consumidor, a fim de se observar o conceito de vulnerabilidade a tutela do mais fraco em nível regional.

Vale ressaltar, ainda, que o presente trabalho retoma vátios trabalhos desenvolvidos nos primótdios da proteção do consumidor no Mercosul, especialmente as publicações da Revista de Direito do Consumidor, pois tais obras discutem o conceito de consumidor, fundamental para a análise da noção de vulnerabilidade.

\section{A NOÇÃO DE VULNERABILIDADE NO MERCOSUL}

A) A Construção do Conceito de Vulnerabilidade: Análise da Doutrina do Mercosul

1 LORENZETTE, Ricardo Luis. Fundamentos do Direito Privado. Trad. Véra Maria Jacob de Fraderá, São Paulo: RT, 1998, p. 137. ESPANES, Luís Moisset. TINTI, Guillermo P. Consideraciones sobre el Consumo e el Derecho del Consurnidor. Rev. Faculdad de Derecho y Ciencias Sociales-Universidad Catolica de Córdoba, tomo II, ano 1999, p. 85-100. ALTERIN], Atílio Anibal. Os Contratos de Consumo e as Cláusulas Abusivas. RDC, n. 15 , jul./set. 1995 , p. 5-19, p. 12 e CABANA, Roberto M. Lopez. Defensa Jurídica de los más débiles, $R D C$, n. 28, out./dez. 1998 , p. 7-21, p. 7.

2 BENJAMMM, Antônio Herman Vasconcelos, no introduzir a obra sobre a vulnerabilidade: MORALS, Paulo Valério. Cádigo de Defesa do Consumidor - oprincipio da vulnerabilidade no contrato, na publicidade e nas demais práticas comerciais. Potto Alegre: Sintese, 1999. 
Embora as leis de proteção ao consumidor não apresentem o mesmo caráter protetivo, a noção de vulnerabilidade apresenta-se coesa para os doutrinadores dos diferentes países do Mercosul.

Para a doutrina argentina, a regra de proteção ao consumidor encontra origens muito remotas. O grande civilista Ricardo LOREZENTTI afirma que a existência de princípio de interpretação em favor do devedor evoluiu até chegar ao favor debilis, em benefício do consumidor, e, a seguir, contemplou o cidadão privado. Esta idéia refere-se à evolução da figura do devedor em Roma. Nos primórdios, o crédito era principalmente um senhorio sobre determinados atos da conduta do obrigado. Ocorreu, posteriormente, uma evolução, em que o devedor deixou progressivamente de ser uma coisa para ser tratado ou considerado pessoa. De fato, é conhecida a transformação do Direito Romano através da Lei Poetelia papiria, e conhecido o critério da benignitas, próprio da ética cristã posterior. Foram-se, então, conformando um núcleo de princípios, tais como fawor libertativ, favor debitoris, contra stipulatorem. O princípio do favor debitoris tem origem protecionista e remonta à época medieval, onde se protegia o devedor de créditos abusivos. Considerava-se que a parte débil era o devedor ${ }^{4}$. Houve, posteriormente, uma adaptação desse princípio do favor debitoris para ofavor debilis.

$\mathrm{Naa} \mathrm{sociedade} \mathrm{moderna,} \mathrm{percebeu-se} \mathrm{que} \mathrm{muitos} \mathrm{devedores} \mathrm{são} \mathrm{fortes} \mathrm{e} \mathrm{alguns} \mathrm{credores}$ débeis. Este fenômeno origina-se com os operários-credores-débeis e seus empregadoresdevedores-fracos, em relação ao salário. Houve uma mudança importante: a legislação protetiva, vigente desde meados do século, estava endereçada a uma determinada categoria de pessoas. As noções de credor ou devedor, apesar de serem conceitos jurídicos gerais, atendem à situação de um indivíduo em relação bilateral. Em compensação, os novos conceitos, como trabalbador ou locatário, levam em consideração, progressivamente, a posição estrutural no mercado. Este fenômeno vai se acentuando aré que as conotações telativas à posição obrigacional acabam por desaparecer: credor-devedor ou a tipologia contratual trabalhador, locatário. Começa-se a utilizar un termo genérico: consumidor. Como se sabe, a noção de consumidor se relaciona ao ato de consumo e, não, especificamente, com a qualidade de credor ou devedor ou com um contrato em particular, englobando uma quantidade gtande de contratos distintos ${ }^{5}$. Contudo, se percebe, segundo Lorenzetti, que já não há apenas um princípio favor debilis, mas sim um princípio em favor do indivíduo particular, pois, em algumas legislações, sem abandonar o caráter contratual da noção de consumidor, estende-se a legitimação aos que sofrem prejuizos derivados do contrato, inobstante não serem contratantes, tais como os meros usuários, o familiar, o convidado ou o grupo relacionado ao consumidor (aqui tratados de bystanders). Assim, o consumidor é substituido por um individuo particular, superando-se a noção de consumo pela de qualidade de vida e colocando-se a pessoa como centro do ordenamento jurídico ${ }^{6}$.

\footnotetext{
3 LORENZETTT, Fundamentos, p. 137.

4 LORENZETTI, Fundamentos, p. $138 / 9$.

5 Iदł., ibjid., p. 141.

6 Id., ibid., p. 143/4.
} 
Para ESPANES e TINTI ${ }^{7}$, a vulnerabilidade jurídica também está vinculada à regra romana do favor debitoris. Igualmente demonstram que não é novo esse caráter de vulnerabilidade, no sentido de que se refere à forma como devem ser interpretados os contratos envolvendo o consumidor. A noção de vulnerabilidade, dessa forma, não representa uma revolução, mas a evolução de um aspecto que já preocupava os jurisconsultos da Antigüidade. E por esse motivo, também, referirem que o juiz, ao interpretar a lei de defesa do consumidor, deve fazê-to em favor do consumidor, ou favor debitoris, ou favor debilis. No Brasil, Leonir BATISTI' refere, analisando a legislação dos países do Mercosul, que a proteção do débil jurídico deu-se através do art. $3^{\circ} \mathrm{da}$ Lei do Consumidor Argentina que prevê, na hipótese de dúvida, a interpretação mais favorável ao consumidor. Dessa forma, conforme se verá, embora somente a lei brasileira refira expressamente o termo vulnerabilidade, ela está presente em todas as leis dos países do Mercosul.

A doutrina argentina apresenta outras formas de caracterização da vulnetabilidade do consumidor: pode decorrer da forma de contratação", pois há mais possibilidade de se estipularem cláusulas abusivas nos contratos de adesão. Outra forma de vulnerabilizar o sujeito na relação de consumo são as técnicas de venda, tais como as ofertas fora do estabelecimento comercial, as possibilidades de venda a crédito, os consórcios, as vendas com prêmios ou brindes. Assim, embora ainda não seja membro efetivo do Mercosul, o Chile também nos traz doutrina que refere os contratos à distância como forma de vulnerabilidade do consumidor, já que o ele não tem a possibilidade de verificar o bem ${ }^{10}$. Também refere que a vulnerabilidade do consumidor é juridica, por não apresentar efetiva capacidade de negociação, problema rípico dos contratos standard e das condiçöes gerais de contratação".

Contudo, o principal fator, como também ressalta STIGLITZ ${ }^{12}$, além da possibilidade de cláusulas abusivas e da forma de venda, são as irregularidades e deficiências da publicidade e da informação sobre produtos e serviços. A informação deformada ao consumidor (que por si só, muitas vezes, já apresenta dificuldade em compreender a informação) impede uma escolha racional do produto ou serviço. De faro, náda mais vulnerável do que o indivíduo após ser submetido a uma seção de publicidade subliminar, por exemplo.

- ESPANES. TINIT, Consideraciones, p. 97/8. No mesmo senudo: ALTLRINI, Os Contratos, p. 12 e CABANA, Defensa, p. 7.

8 BATISTI, Leonir. Direito do Consumidor para o Mercosul - enfoque jurídico e econòmico dos Blocos de Integração. Curitiba: Juruá, 1998, p. 440/3.

2 STIGLITZ, Gabriel. O Direito Contratual e a Proteção Juridica do Consunidor. RDC, n. 1, mar. 1992, p. $184-200$, p. 187.

10 RAMÍREZ, Patricio Carvajal. Sugerencias para um Derccho de Consumo Unitário. Revista Cbilena de Derecho, v. 29, B., 1, enero/abril 2002, p. 127/13, p. 132.

1 Id., ibid., p. 135.

12 STIGLITZ, O Direito Contratual, p. 191. 
Ao comentar o Código de Defesa do Consumidor Brasileiro, BENJAMIM ${ }^{13}$, descrevendo a publicidade sublimiar, refere a experiência feita nos Estados Unidos, em 1957, em que una platéia de cinema foi induzida ao consumo de Coca-cola e de milho, mediante a inserção de mensagens de est́mulo na fita de exibição. No mesmo sentido, posiciona-se a doutrina uruguaia. Para Gustavo ORDOQUI CASTILLA ${ }^{14}$, na fase pré-contratual, o consumidor aparece com una primeira grande deficiencia que é a falta da informação devida ou adequada. Refere, também, que o dever de informação começou a ser descoberto pela jurisprudência em vários contratos, na medida em que os consumidores ingressavam na relação de consumo, a partir da legítima confiança no fornecedor, que os dispensava de realizar investigações, averiguações, ou tratativas ${ }^{15}$. Chega o mesmo autor a afirmar ${ }^{16}$ ser a desigualdade entre as parte contratantes o fundamento do dever de informar.

Sem dúvida, portanto, a questão da informação é fundamental para definir a vulnerabilidade do consumidor. Nesse sentido, vale mencionar que, segundo Lorenzetti, para que se considere o indivíduo como centro do Direito Privado, deve ele apresentar o direito a estar informado, juntamente com o direito a informar. Sabe-se que a atividade econômica mobiliza-se em virtude de uma aliança cada vez mais sólida com o conhecimento: isso já acontece há tempos, porém é na atualidade que se vislumbra o real protagonismo do saber. Os mercados criam-se pelo surgimento de novos inventos, os produtos são melhores ou piores fundamentalmente pelo avanço científico que levam incorporados. Na sociedade atual, pois, há una diferenciação entre quem provê profissionalmente produtos e serviços e quem os consome, e o Direito Privado dispõe de normas delimitadoras desse poderio na relação bilateral. ${ }^{17}$ Importante referir que estes campos não coincidem totalmente ao do poderio econômico. Em geral há coincidência da superioridade econômica com a superioridade técnica, mas também há o profissional individual que não contrata em grandes quantidades, nem rem poder econômico e apresenta superioridade técnica. Daí as palavtas do autor argentino: "É a fenda informativa entre ume outro contratante, eque opera como desequilibrantedo igualemprazamentoprestatórion'18.

Retomando-se, então, a doutrina hispânica analisada, são características da vulnerabilidade dos consumidores: forma ou técnica de contratação, por permitir mais facilmente a inserção de cláusulas abusivas, também as técnicas de venda, o marketing, a

${ }^{13}$ BENJAMIN, Antônio Hermam Vasconcelos. A Publicidade no Código de Defesa do Consumidor. In: BEN]AMIN, Antônio Hermam Vasconcelos et al. Código Brasileiro de Defesa do Consumidor comentado pelos autores do Anteprojeto. Rio de Janeiro: Forense Universitária, 1995, p. 77-139, p. 90.

14 CASTILLA, Gustavo Ordoqui. Deber de Información em la Ley 17.189, de 20 de Setrembre de 1999. $R D C$, s. 34, a. 9 , abril-jun. $/ 2000$, p. $45-77$, p. 47.

15 Id., ibid., p. 48 .

${ }^{16}$ Id., ibid., p. 64/5.

17 LOREZENTTT, Fundamentos, p. 512/3.

is Td., ibid., p. 514. 
publicidade são formas de vulnerabilizar o consumidor, bem como a falta de informação técnica. Deve»se mencionat, ainda, conforme expressa ITURRASPE, que uma das formas de proteçã̃o dos vulneráveis constitui a inversão do ônus da prova em favor do consumidor ${ }^{13}$.

No Brasil, Cláudia Lima MARQUES ${ }^{20}$ conceitua a vulnerabilidade como um estado da pessoa, um estado inerente de tisco ou um sinal de confrontação excessiva de interesses identificados no mercado, uma situação permanente ou provisória, individual ou coletiva, que fragiliza e enfraquece o sujeito de direitos. Descordando de BENJAMIN ${ }^{21}$, a professora gaúcha refere que a vulnerabilidade não é fundamento das regras de proteção do sujeito fraco, é apenas a explicação destas regras ou da atuação do legislador. Essa vulnerabilidade, pois, pode ser técnica, quando o comprador não possui conhecimentos específicos sobre o objeto que está adquirindo e, portanto, é mais facilmente enganado quanto às características do bem ou quanto à sua utilização, o mesmo em matéria de serviços; também pode ser jurídica ou científica, quando há falta de conhecimentos de contabilidade, de economia. Já a vulnerabilidade fática ou sócio-econômica, considera-se a partir da perspectivá da contraparte, deve-se em razão do seu grande poder econômico ou da essencialidade dos serviços oferecidos ${ }^{22}$.

Na classificação referida, percebe-se que as vulnerabilidades técnica e jurídica ou científica vão influenciar mais no momento da contratação, já a vulnerabilidade fática ou sócio-econômica vai atingir mais a execução do contrato. Utilizando-se, então, a doutrina do Mercosul, pode-se afinnar que as técnicas de venda, o marketing, a publicidade enquadram-se mais na vulnerabilidade técnica, enquanto a vulnerabilidade decorrente dos contratos de adesão, da possibilidade de cláusulas abusivas apresenta-se mais relacionada à vulnerabilidade fática ou sócio-econômica ${ }^{23}$.

Analisando-se os contratos de adesão, que é o método próprio da contratação consumeirista, verifica-se que nem todo contrato de adesão se dá entre consumidores ${ }^{24}$. Por exemplo, a maioria dos contratos internacionais, principalmente entre empresas nacionais e multinacionais, é padronizada, em que una das partes estipula as cláusulas e as envia à outra parte, que, de acordo com suas necessidades, adere. A discussão que se costuma travar é que, muitas vezes, senão na maioria, o grau de vulnerabilidade (técnica, jurídica ou econômica) vai variar entre as empresas. Aparecerão, portanto, cláusulas abusivas também nas relações entre

"TTURRASPE, Cláusulas, p. 62.

20 MARQUES, Contratos, p. 269/70.

${ }_{21}$ BENJAMIN, Comentários, p. 78.

22 MARQUES, Cláudia Lima. Contratos no Código de Defesa do Consumidor, 4 ed., São Paulo: Revista dos Tribunais, 2002, p. 269/272.

${ }^{23}$ A partir dessa classificação serão analisadas as leis de proteção do consumidor dos páses do Mercosul, na segunda parte do trabalho.

${ }^{24}$ I'TURRASPE, Jorge Mosset. Las Cláusulas Abusivas em la Contratación (informe del derecho argentino), $R D C$, n. 44, out./dez. 2002, p. 49-67, p. 55. 
empresários. Ora, há muitos casos de pequenas empresas que, ao ingressarem numa relação de consumo, não dispõem do mesmo poder econômico da parte adversa com quem se contrata.Assim, deve-se mencionar que certamente todo consumidor é vulnerável, mas nem todo vulnerável é consumidor ${ }^{25}$.

Pottanto, ao se tratar da noção de vulnerabilidade deve-se retomar a discussão acerca do conceito de consumidor. No Brasil, muitos doutrinadores, especialmente os vinculados à redação do código, aderem à chamada teoria finalista, bem expressa por Cláudia Lima MARQUES ${ }^{26}$. Na doutrina finalista, o consumidor seria o não-profissional, pois o fim do CDC é tutelar de maneira especial um grupo da sociedade mais vulnerável. Portanto, a construção do conceiro de consumidor envolve necessariamente o desenvolvimento do conceito de vulnerabilidade. Refer ${ }^{27}$, também, que os finalistas evoluíram para uma posição mais branda, embora ainda teleológica, no sentido de aceitar a possibilidade do Judiciário reconhecer a vulnerabilidade de uma pequena empresa ou profissional, quando adquire, por exemplo, um produto fora de seu campo de especialidade. Interpreta-se o conceito de consumidor de forma extensiva, isto é, protegendo o mais fraco na relação de consumo e concedendo a aplicação das normas especiais do Estatuto analogicamente a esses profissionais. Também Benjamin, um dos mestres precursores de toda questão consumeirista no Brasil, também conceitua como destinatário final do produto e do serviço ${ }^{28}$.

Dentre os argentinos, ALTERINI ${ }^{29}$ refere que há conceitos objetivos e subjetivos de consumidor. Os conceitos objetivos contêm um componente positivo consistente na exigência de que $O$ ato de intermediação seja realizado por um profissional ou comerciante e o elemento negativo referemse ao sujeito qualificado como consumidor, que não deve atuar profissionalmente. Já nas definições subjetivas há também um componente positivo, isto é, para ser considerado consumidor o sujeito deve destinar a aquisição do produro para uso pessoal ou familiar, já que a qualidade profissional do intermediário resulta indiferente. São incluídos no conceito de consumidor ou a ele equiparados os chamados bystanders, que são os espectadores ou terceiros envolvidos na relação de consumo ${ }^{30}$. Daí a importância em se definir a vilnerabilidade, já que é ela, e não apenas o consumidor juridicamente reconhecido, que determinada toda a sistemática protetiva. E os bystanders vêm a confirmar isso, embora tenha que se ter presente sempre algum critério restritivo. No caso da doutrina aqui analisada, o critério finalista é determinante. Tanłbém nos informa ALTERINI ${ }^{31}$ a noção de sub-

25 Uma possivel solução para a proteção dos vulneríveis não consumidores no Brasil, a partir do Novo Código Civil e de suas cláusulas getais, como a Boanfé Objetjva e Função Social dos Contratos, talvez esteja nesses paradigmas de lealdade, de eticidade e de efeitos contratuais justos e equânimes.

26. BENJAMIN, Comentários, p. 78. e MARQUES, Contratos, p. 252/3.

${ }^{27}$ MARQUES, Contratos, p. 254.

${ }^{28}$ BENJAMTN, Comentários, p. 78.

29 ALTERINI, Os Contratos, p. 5.

36. ALTERINI, Os Contratos, p. 6.

31. Id, ibid., p. 7. 
consumidor ou de consumidor particularmente frágil, tais como os consumidores de produtos farmacêtuticos de venda livre ou as crianças consumidoras, que por si só já são vulneráveis.

Do exposto, verifica-se que a vulnerabilidade de caráter econômico, porque própria de telações contratuais - os negócios jurídicos servem, em sua maioria, para regular relações econômicas - senpre foi tutelada pela Direito: a regra do favor debitoris demonstra bem isso. Contudo, houve uma evolução nessa tutela, de acordo com as alterações experimentadas pela sociedade. Na sociedade massificada, o vulnerável pode não ser apenas o devedor, mas igualmente o credor, e não apenas um membro da relação contratua ${ }^{32}$, atingindo também terceiros, hoje conhecidos por bystanders. Todas as leis de defesa do consumidor dos países do Mercosul, conforme se verá, reconhecem essa debilidade, mesmo que de forma não expressa, como o fez a lei brasileira: todas apresentam alguma regra no sentido de que a interpretação das regras contratuais (ou das disposições da oferta, como na uruguaia) deve ser mais favorável ao consumidor ${ }^{33}$, exptimindo a ratio do sistema.

Quanto à caracterização da vulnerabilidade, embora apresente graduação (tais como os sub-consumidores), a dourrina analisada informa várias formas de identificá-la. É no Brasil, porém, através da doutrina de Cláudia Lima Marques, que seus caracteres serão trabalhados de forma mais sistemática: vulnerabilidade técnica, jurídica e econômica. Agregando-se, então, a doutrina hispânica à brasileira, percebe-se que, mesmo permeando toda a relação contratua ${ }^{34}$, desde a fase pré até a fase pós-contratual, as vulnerabilidades técnica e juridica se farão mais presente na fase da formação do vínculo contratual, enquanto a vulnerabilidade econômica se constate mais na fase de execução do contrato. Ademais, na vulnerabilidade técnica podem ser enquadradas as técnicas de venda, marketing, publicidade, fá que se referem à ausência de informações específicas sobre o objeto que está sendo adquirido. $\mathrm{Na}$ vulnerabilidade jurídica ou científica, enquadram-se os deveres de transparência do fornecedor, já que o consumidor apresenta um déficit de conhecimentos específicos sobte as ciências envolvidas na contratação. Na vulnerabilidade fática ou econômica, enquadram-se as hipóteses de cláusulas abusivas, que decorrem, em sua maioria, do método de contratação: condições gerais e contratos de adesão.

${ }^{32}$ Também Gonzalo Sosso nos esclarece que a relação de consumo independe do contrato, pois pode emanar de outras fontes obrigacionais, como fatos ilicitos - entre os quais se incluem os casos de abuso de direito -, simples fatos juridicos e atos jurídicos laterais e unilaterais (aí incluídos os contratos). Tanto isso é verdadeiro que a Lei de Defesa do consumidor Argentina utiliza a noção de relação juridica de consumo e não de contrato de consumo, apenas. Dessa forma, então, pode ser incluida a etapa pré-contratual. Nesse sentido, SOSSO, Gonzalo. Daños Derivados Del Acto de Consumo. RDC, n. 35 , abr./jun. 2000 , p. 9-33, p. 16

${ }_{3.3}$ Cabana refete que a interpretação mais favorável ao consumidor, admitida no art. $3^{\circ}$ da lei argentina relaciona-se tambérn com outra normas que se reservam à parte mais fraca, como a Lei 20.744 sobre contratos de trabalho: CABANA, Defensa, p. 14.

${ }^{34}$ STIGLIT\%, ODireito Contratual, p. 194.

35 ESPANÉS ETINTI, Consideraciones, p. 93/4. 
Observando-se, porém, todos esses caracteres apontadas pela doutrina do Mercosul como referentes à vulnerabilidade, percebe-se que todos apontam para a informação como definidor dela. Será o défícit ou a ausência de informação que define significativamente a vulnerabilidade, por isso são tão definitivas as palavras de Lorenzetti, já referidas: para que o individuo torne-se a figura central do Direito Ptivado, o direito à informação deve ser privilegiado.

B) A Declaração da ONU em Defesa dos Vulneráveis e sua Tutela ras, Constituições Democráticas dos Países do Mercosul

A partir 1840, na Inglaterra e na França, começa a surgir associações de consumidores, ou seja, iniciam-se as reclamações acerca da carestia dos produtos e da sua qualidade. Em 1900, em Nova Iorque e em Paris, surgem as Ligas Sociais de Compradores ${ }^{35}$. O marco do surgimento do Movimento Consumeirista foi, contudo, o discurso proferido pelo Presidente Kennedy, em 1962, no Congresso Norte-americano, onde afirmou: "todos nós somos consumidores, todos somos vulneráueis, e todos nos encontramos, em face do mercado, em uma posicão de debilidade desconcerto" 36

A lição de Newton de LUCCA ${ }^{37}$ demonstra o caráter histórico do Direito do Consumidor, estabelecendo um paralelo entre o Direito Comercial e o Direito do Consumidor, já que o primeiro surgiu no passado por causa da nova força de uma civilização burguesa e urbana, e o segundo decorreu da chamada civilização das massas. O primeiro nasceu para proteger o empresário que exercita profissionalmente uma atividade econômica organizada para a produção ou circulação de bens ou de serviços, enquanto o segundo surge visando a proteger aquele que está do outro lado dessa relação jurídica, que adquire ou utiliza um produto ou um serviço como destinatário final.

Seguindo os dados cronológicos, refere-se ${ }^{38}$, ainda, que em 1973, na Inglaterra, surge o primeiro $A c t$ de defesa do consumidor, em termos de limitação do poder do fornecedor. Em 1974, na Suécia, a Lei sobre a Compra e o Consumo; na Noruega, em 1975, o direito do comprador de reclamar os vícios dos produtos; nos Estados Unidos, o Uniform Comercial Code. $\mathrm{Na}$ Alemanha, a primeira lei data de 1976. Em nivel regional, as primeiras referências encontram-se na Carta de Proteção ao Consumidor do Conselho da Europa (Resolução 543, de 15 de março de 1983) e nas diferentes versões do "programa preliminar para uma política de proteção e informação aos consumidores" da Comunidade Econômica Européia, de 14 de março de $1975^{39}$. Nasce, pois, o Direito do Consumidor como forma de proteger a segurança física e econômica do adquirente de bens e serviços, preponderantemente pessoa física.

36 ALTERINI, Os Contratos, p. 6.

${ }^{37}$ LUCCA, Newton de. O Mercosul e a defesa dos consumidores brasileiros. Revista de Direito do Mercosul. a. 2 , n. 5 , out. 1998 , p. $5-11$, p. 6.

3h BATISTI, Direito, p. 165/6.

39 AlterinI, Os Contratos, p. 6/7 e 12. 
De fundamental importância para o desenvolvimento do Movimento Consumeirista nos países do Mercosul, foi a Resolução 39/248, de 09.05.85, da Assembléia-Geral da ONU, que definiu normas para a defesa do consumidor, revelando que as origens das diretrizes remontam ao final da década de 1970, quando o Conselho Económico e Social da ONU reconheceu a importante influência da proteção ao consumidor sobre o desenvolvimento econômico e social. Nesta Resolução, em matéria contratual, o complexo de soluções legais, judiciais e administrativas previa a seguinte direção $0^{40}$ : a) promoção e proteção dos interesses econômicos dos consumidores; b) acesso dos consumidores a uma informação adequada, que thes permita realizar escolhas corretas, de acordo com os desejos e as necessidades de cada um; c) lealdade das práticas comerciais; comercialização informativa; prevenção e proteção efetiva contra as práticas que possam prejudicar os interesses econômicos dos consumidores e as possibilidades de escolha no mercado; d) proteção contra abusos contratuais, como o uso de contratos standard que favorecem uma das partes, a não inclusão de direitos fundamentais nos contratos, etc. e) tratamento justo aos consumidores nas práticas de promoção, comercialização e venda.

Além da organização regional promovida pelas Nações Unidas, também se deve mencionar o papel da International Organization of Consumers Unions (IOCU) que, em 1986, organizou em Montevidéu sua Primeira Conferência Regional para América Latina e Caribe, convocando as nascentes organizações de consumidores. Meses depois, em março de 1987, as Nações Unidas, também em Montevidéu, impulsionaram a realização de um encontro de autoridades governamentais, a fim de discutir a aplicação das Diretrizes no continente ${ }^{41}$. De fato, as primeiras e muito modestas organizações de consumidores nos países do Mercosul surgem quase de forma clandestina, já que qualquer manifestação de cunho mais social poderia atentar contra os regimes ditatoriais que vigiam nos países latino-americanos. A partir desses movimentos, se esboçam os primeiros projetos tendentes a combater as cláusulas abusivas, a impedir práticas comerciais desleais e a propugnar pela defesa dos interesses difusos ${ }^{42}$.

Vale referir, ainda, que o único país latino-americano a apresentar, ainda na década de 70, uma lei de proteção ao consumidor foi o México ${ }^{43}$, demonstrando mais uma vez seu pioneirismo na defesa dos interesses sociais, lembrando da Constituição Mexicana de 1917, uma das primeiras a reconhecer direiros sociais.

Surgem, então, as Constituições democráticas nos países latino-ameticanos e do Mercosul. Os processos de redemocratização e de constitucionalização iniciam-se na Argentina,

4) STIGLIT"Z, ODireito Contratual, p. 186.

${ }^{41}$ ARRIGHI, Jean Michel. La Protección de los Consumidores y el Mercosur. RDC, n. 1, mar. 1992, p. 124-136, p. 133.

42 BATTSTI, Direito, p. $167 / 9$.

43 ARRIGHI, La protección, p. 132. 
em 1984; no Uruguai e no Brasil, em 1985, e no Paraguai, em 198944. Deve-se ressaltar, portanto, que somente com a democratização foi possível instituir os princípios de proteção ao consumidor nesses países ${ }^{45}$, aliado, é claro, às diretrizes estabelecidas pela $O N U$, sendo que as Constituições Brasileira e Argentina expressamente mencionam a proteção do consumidor como objetivo econômico e social ${ }^{\text {tै }}$ :

A Constituição Argentina vigente, reformada em 1994, apresenta referência ao consumidor nos artigos 42 e 43 , inclusive especificando os direitos do consumidor, o que, por exemplo, a legislação brasileira deixou a cargo do legislador ordinário.

Refere o att 42: "Los consumidores y usuarios de bienes y serviciostienen derecho, en la relación deconsumo, ala protección de su salud, seguridade intereseseconómicos, a una información adecuaday veraz; a la libertad de elección, y a condiciones de trato equitatizo y digno.

Las autoridades proveetán a la protección de esos derechos, a la educación para el consumo, a la defensa de la competencia contra toda forma de distorsión de los mercados, el control de los monopolios naturales y legales, al de la calidad y eficiencia de los servicios públicos, y a la constitución de asociaciones de consumidores y de usuarios.

La legislación establecerá procedimientos eficaces para la prevención y solución de conflictos, y los marcos regulatorios de los servicios públicos de la competencia nacional, previniendo da necesaria participación de las asociaciones de consumidores y usuarios y de las provincias interesadas, en los organismos de control,"

Já o art. 43 preceitua: "Toda persona puede interponer acción expedita y rápida de amparo, siempreque no exista medio judicial más idóneo, contra todo acto u omisión de autoridades públicas o de particulares, que en forma actual o inminentelesione, restrinja, altere o amenace, con arbitrariedado ilegalidad manifiesta, derecho y garantías reconocidos por esta Constitución, un tratado o unaley. (...)

Podrán interponer esta acción contra chalquier forma de discriminación y en lo relativo alos derechos que protegen al ambiente, a la competencia al usuario y al consumidor, asicomo alos denechos de incidencia colectiva en general, el ajectado, el defensor del pueblo y las asociaciones que propendan a esos fines, registrados conforme a la ley, lo que determinará los requisitos y formas de su organización. (...".

A Constituição Democrática do Brasil, de 1988, eleva o direito do consumidor à categoria de direito fundamental, em seu arr. $5^{\circ}$, XXXII. Ele está também mencionado nos artigos $150, \$ 5^{\circ}, 170$, e 129 , III, da CF:

44 Id., ibid., P. 133.

${ }^{45}$ STIGLITZ, Gabriel. O Direito do Consumidor e as Práticas Abusivas - realidade e perspectiva na Argentina. RDC, n. 3, set./dez. 1992, p. 27-35, p. 27.

4t BATISTI, Direito, p. 169/182. 
Art. 50: "Todos são iguais perante a lei, sem distinção de qualquer natureza, garantindo-se aos brasileiros $e$ aos estrangeiros residentes no País a inviolabilidade do direito à vida, à liberdade, à igualdade, à segurança è propriedade, nos termos seguintes:

XXXII - o Estado promoverá, na forma da lei, a defesa do consumidor."

Art. 150, $\$ 5^{\circ}$ : "A lei determinará medidas para que os consumidores sejam esclarecidos acerca dos impostos que incidam sobre mercadorias e serviços".

Art. 170: "A ordem econômica, fundada na valorização do trabalbo bumano ena livre iniciativa, tem por fim assegurar a todos existência digna, conforme os ditames da justiça social, observados os seguintes princípios:

\section{$V$-defesa do consumidor."}

Art. 129: "São funções institucionais do Ministério Público:

III-promover o inquérito civil e a açâo civil pública, para a proteção do patrimônio público e social, do meio ambiente e de outros interesses difusos e coletivos."

Tanto no Brasil quanto na Argentina há a figura de um defensor do povo, agindo na promoção dos interesses dos consumidores. No Brasil, o Ministério Público tem tido um papel fundamental na defesa dos vulneráveis. Conforme se observa na redação dos artigos, pois, tanto a Argentina como o Brasil colocam a proteção dos consumidores como objetivo econômico esocial. ${ }^{47}$

A Constituição Paraguaia é de 1992: embora não se apresente o direito do consumidor como objetivo econômico e social, há previsão de proteção dos interesses dos consumidores nos artigos $27,38,72$, também com referência ao Defensor do Povo, lá igualmente chamado de Ministério Público ${ }^{48}$.

A1t. 27: "La ley regularála publicidad para mejor protección de los derechos del niño, del joven, del analfabeto, del consumidory dela mujer".

Art 38: "Toda persona tiene derecho, individual o colectivamente, a reclamar a las autoridades públicas medidas para la defensa del ambiente, de la integridad de hábritat, dela salubridadpública, del acervo cultural nacional, de los intereses del consumidor y de otros que por su naturaleza jurídica pentezan a la comunidad y bagan relación con la calidad de vida y con el patrimonio colectivo".

4) Dentre outros, MARQUES, Cláudia, Direitos do consumidor no Mercosul: algumas sugestões frente ao impasse. RDC, n. 32, out./dez. 1999, p. 16-44, p. 18.

48 Também analisa as Constituições dos países do Mercosul com relação à proteção do consumidor: FEKETE, Elisabeth Kasznar. A Proteção do Consumidor como Instrumento de Aperfeççamento da Integração Econômjca no Mercosul - com especial relevo para o relacionamento com o direito das marcas e da concorrència desleal. $R D C, \mathrm{n} .20$, out./dez. 1996, p. 112-126, p. 116. 
Art. 72: "El Estado velará por el control de calidad de los productos alimenticios, en las etapas de producción, importación y comercialización. Asimismo, facilitará el acceso de sectores de escasos recursos a los medicamentos considerados esenciales."

O Uruguai, com a Constituição reformada em 1996, nada traz a respeito da criação de uma lei especifica de consumidores. Há apenas menção periférica ao se tratar da execução de serviço público, da saúde pública e da proibição da usura. Neste sentido, ressalta-se que o Uruguai foi o último país a adotar uma lei em defesa dos consumidores, em 1999.

Art. 24: "El Estado, los Gobiernos Departamentales, los Entes Autónomos, los Servicios Descentralizadosy, en general, todoórgano del Estado, serán civilmenteresponsables del daño causado a terceros, en la ejecución de los servicios públicos, conflados asu gestión odirección."

Art 44: "El Estado legislaráen todas las cuestiones relacionadas con la salude higiene públicas, procurando el perfeccionamien to fisico, moral y social de todos los habitantes del párs."

Art 52: "Probibeselausura. Es de orden público la ley que señalelímitemáximo al interés de los préstamos. Estadeterminarála pena a aplicarsea los contrazentores."

\section{II * A VULNERABILIDADE NO MERCOSUL}

A) A Noção de Vulnerabilidade e a Proteção dos Mais Fracos nos Ordenamentos Jurídicos dos Países do Mercosul: Comparativo das Leis de Defesa do Consumidor.

A partir, então, das diretrizes para a proteção do consumidor estabelecidas pela Assembléia Geral das Nações Unidas, através da Resolução n. ${ }^{\circ}$ 39/248, de $1995^{41}$, foram-se elaborando as leis de defesa do consumidor nos países do Mercosul. O primeiro país a aprovátla foi o Brasil, em 1990, vindo a influenciar a legislação dos demais países.

A análise da concepção de vulnerabilidade na doutrina do Mercosul permitiu constatat a importância dada à informação, por interferir diretamente no grau de racionalidade do consumidor. Quanto mais informado estiver, mais capaz de escolhas conscientes e livres. Essa predominância da informação é percebida ao longo de todo o processo de contratação, desdobrando-se a vulnerabilidade em técnica, jurídica e econômica. Resta agora verificar de que forma essa vulnerabilidade encontra-se tutelada nas leis de defesa do consumidor dos países componentes do Mercosul. Para tal, faz-se importante, igualmente, a análise do conceito de consumidor nas diferentes leis, assim como a possível inclusão ou equiparação das pessoas jurídicas e dos chamados bystanders.

49 ARROYO, Diego P. Fernández Arroyo et al. Modalidades contractuales específicas. In: ARROYO, Diego P. Fernandez Arroyo (coord.). Derecho Internacional Privado de los Estados del MERCOSUR Argentina, Brasil, Unuguaye Paraguay. Buenos Aires: Zavala, 2003; p. 1027. 
Pois bem, em 1993, a Argentina aprova sua Ley 24.240 de Defensa del Consumidor, influenciada pela promulgação do Código de Defesa do Consumidor no Brasil ${ }^{50}$. Em julho de 1998, é promulgada a Ley 24.999 , modificando os artigos 11,13 e 14 do capitulo IV (Cosas muebles no consumibles) e art. $40^{51}$ do capítulo X (Responsabilidad por daños). Com relaçãoà vulnerabilidade, então, conforme já referido", há menção no art. $3^{\circ}$ da lei: "(...) En caso de duda, se estará siempre a la interpretación más favorable para el consumidor." Já o conceito de consumidor encontra-se prevista no art. $1^{\circ}$ da Lei $24.240:$ "(..) Se consideran consumidores o usuarios, las personas físicas o jurídicas que contratan a título oneroso parasu consumo final o beneficio propio o de su grupo familiar o social". Vê-se, pois, que näo há referência aos terceiros relacionados ao consumo. Vale, igualmente, referir que no art. $2^{\circ}$ se estabelece uma norma excludente do conceito de consumidor: "No tendrán el carácter de consumidores o usuarios, quienes adquieran, almacenen, utilicen o consuman bienes o servicios para integrarlos en procesos deproducción, transformación, comercialización oprestación aterceros".

Com relação à proteção às diferentes formas de vulnerabilidade, verifica-se que a vulnerabilidade técnica (técnicas de venda, marketing, publicidade) - presente principalmente na fase da contratação - é protegida na lei Argentina através de regras sobre a publicidade (artigos $7^{\circ}$ e $8^{\circ 53}$ ), o dever de informação (art. $4^{054}$ ) e a proibição de práticas abusivas na fase pré-contratual (art. 34 e 37 - in fine $e^{55}$ ). Não há, porém, qualquer

50 FEKEETE, A Proteção, p. 115.

51 Depois de criticas doutrinárias a respeito do veto presidencial, incluitu-se na lei a responsabilidade solidátia dos fornecedores, através da Lei $0 .{ }^{\circ} 24.999$, de $1^{\circ}$ de julho de 1998 (publicada na Revista de Direito do Consumidor, n. 27). Dentre os críticos: GHERSI, Carlos A., La Ley de Defensa de los Derechos del Consumidor y la Fragmentación Juridica del Sistema de la Reparación de Daños. In: GHERSI, Carlos A. (Org.). MERCOSUR - Perspectivas desde el Derecho Privado-Parte segunda. Buenos Aires: Editorial Universidad, 1996, p. 229.

52 Páginas 6 e 7 do presente trabaho.

${ }_{53}$ "Ant. $7^{\circ}$. (Oferta) La oferta dirigida a consumidores potenciales indeterminados, obliga a quien emite durante el tiempo en que se realice, debiendo contener la fechaprecisa de comienzo y de finalización, asícomo también sus nodalidades, condiciones olimitaciones.

La revocación de la oferta hecha pública es eficaz una vez que haya sido difundida por medios similares a los empleados para hacerla conocer."

"Art. $8^{\circ}$ - (Efectos de la publicidad) Las precisiones formuladas en la publicidad o en anuncios, prospectos, circulares u otros medios de difusión obligan al oferente y se tienen por incluidas en el contrato con el consumidor".

${ }_{54}$ "Ant. 4". Información) Quienes produrcan, importen, distribrnen ocomercialicen cosas opresten servicios, deben sumimistrar a los consumidores o ustarios, en forma cierta y objetiva, información weraz, detallada, eficaz y sufciente sobre las características esenciales de los mismos."

55 "Art.34-(Revocación de aceptación) En los casos de los artículos 32 (venta domiciliaria y 33 (venta por conrespondencia y otrass, el consumidor tiene el derecho de revocar la aceptación durante el plazo de 5 dias corridos, contados a partir de la fecha en que se entregue la cosa o se Cléber el contrato, lo ultino que ocurra, sin responsabilidad alguna Esa facultad no puede ser dispensada ni renunciada. (...).". 
menção à proibição de publicidade enganosa ou abusiva, nem à necessidade de prova da veracidade das informaçōes veiculadas em anúncios - importante forma de tutela dessa vulnerabilidade. Com relação à vulnerabilidade jurídica (necessidade de transparência da relação de consumo), que também se mostra mais na fase de contratação, sua proteção na lei Argentina se dá através dos princípios de transparência (art. $4^{\circ}$ e $6^{\circ 56}$ ) e da possibilidade de revogaçăo da proposta (art. $7^{057}$ ). Por fim, quanto à vulnerabilidade fática ou econômica (cláusulas abusivas, condições gerais de contratação e contratos de adesão), mais freqüenta na fase de execução do contrato, a Lei Argentina regula as condições gerais e os contratos de adesão (art. $38^{58}$ ), bem como refere una lista exemplificativa de cláusulas abusivas no art. $37^{5 \%}$.

A lei brasileira, por sua vez, a primeira a entrar em vigor no Mercosul, em 1990, de número 8.078, é denominada Código de Defesa do Consumidor. A vulnerabilidade aparece mencionada, de forma expressa no artigo 4", I: "A Política Nacional das Relações de Consumo tem porobjetivo a tendimento das necessidades dos consumidores, o nespeito àsuadignidade, saúdee seguranca, aproteção de seus interesses econômicos, a melboria da sua qualidade de vida, bem como a transparênciae harmoniadas relaçôes de consumo, atendidos os seguintes princípios:

I-reconhecimento da vulnerabilidade do consumidor no mercado de consumo". Também há referência ̀̀ interpretação mais favorável ao consumidor - art. 47: "As cláusulas contratuais serão interpretadas de maneira maisfazorável ao consumidor". Com relação ao conceito de consumidor, abre bastante o leque dos vulneráveis, segundo o art. $2^{\circ}$; "Consumidor é toda pessoa fisica ou jurídica que adquire ou utiliza produto ou servico como destinatário final Parágrafo ínico. Equipara-se a consumidor a coletividade de pessoas, ainda que indetermináveis, que baja intervindo nas relaçöes de consumo ". Posteriormente, há referência ao consumidor nos artigos 17 e 29 , havendo clara inclusão dos bystanders.

${ }_{56}$ "Art. 6" (Cosas y servicios riesgosos) Las cosasy servicios, incluidos los servicios públicos domiciliarios, chya utilización pueda suponer un riesgo para la salud o la integridad física de los consumidores o wswarios, deben comencializarse olservando los mecanismo, instrucciones y normas establecidas o razonables para garantizar la seguridad de los mismos (...).

\$7 "Ant. $7^{\circ}$ (Ojerta)(...) La revocación de la of erta hecha pública es eficaz una vez que hrova sido difundida por medios similares alos empleados parabacerlaconocer:"

5" "Ant. 38 - (Contrato de adhesión. Contratos en formularios) La autoridad de aplicación vigiláá gue los contratos de adhesión osimilares, no contengan cláusulas de las previstas en el articulo anterior. La misma atribución se ejercerá respecto de las clátustlas uniformes, generales o estandardizadas de los contratos, hechos en formularios, reproducidos en serie yen general, cuando dichas cláusulas bayan sido redactadas unil ateralmente por el proveedor de la cosa o servicio, sin que la contraparte tutviere posibilidad de discutirsu contenido."

5) "Art.37-(Interpretación)-Sin perjuicio de la validez del contrato, se tendrán por no convenidas: a) las cláusulas que desnaturalicen las obligaciones o limiten la responsabilidad por daños; b) las cláusulas que importen remuncia o restricción de los derechos del consumidor o amplien los derechos de la ovra parte; c) las cláusulas que contengan cualquier precepto que imponga la inversión de la carga de la prueba en perjuicio del consumidor. (...)".

6) "Art. 17. Para efeitos desta Seção (Responsabilidade pelo fato do produto ou servico) equipara-se a consumidor todas as vítimas doevento."

"Art. 29. Para fins deste Capitulo (Das práticas comerciais) e do seguinte, equipara-se aos consumidones todas as pessoas determináveis ou nã், expostas às práticas nele previstas." 


\section{Com relação à vulnerabilidade técnica, nos artigos $30 \mathrm{e} 35, \$ 1^{\circ}$,}

"Art. 30. Toda informação ou publicidade, suficientemente precisa, veiculada por qualquer forma ou meio de comunicação com relação a produtos e serviços oferecidos ou apresentados, obriga o fornecedor que a fizer ou dela se utilizar e integra o contrato que vier a ser celebrado."

\section{"Art. 37. É proibida toda publicidade enganosa ou abusiva:}

há referência à publicidade com função de oferta; no art. 30, ao dever de informação;

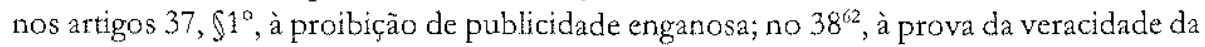
oferta cabendo ao fornecedor, e, por fim, à proibição de práticas abusivas na fase de précontratação (art. $39^{63}$ ). Com relação à vulnerabilidade jurídica, o art $31^{64}$ refere o dever de transparência na oferta $e$ o art. $35^{\text {6. }}$ prevê a possibilidade de revogação da oferta apenas na hipótese de indenização. Por fim, quanto à vulnerabilidade fática ou econômica, a lei brasileira refere as condições gerais e os contratos de adesão (artigos 46 e $54^{66}$ ) e, no art. $51{ }^{67}$, há uma lista exemplificativa de cláusulas abusivas.

61 "Ant 30 . Toda informação on publicidade, sufuiventemente precisa, veiculadapor qualquer forna ou meio de comunicação com relação a produtos e serviços oferecidos ou apresentados, obriga fornecedor que a fuzer ou dela se utilizar e integrao contrato que vier a ser celebrado."

"Art. 37. É proibida toda publicidade enganosa ou abusiva:

\10. É enganosa qualquer modalidaçe de informação ou comunicação de carater publicitário, inteira ou parcialmente falsa, ou, por qualq̧uer outro modo, mesmo por omissão, capaz de induzir em erro o consumidor a respeito da natureza, característica, qualidade, quantidade, propriedade, origem, preço ou quaisquer outros dados sobre produtos e serviços."

${ }^{62}$ "Art. 38. O ônus daprova da veracidade comesão da infornação on comunicafão publicitária cabe a quem os patrocina."

‘3 "Art. 39. é vedado ao fornecedor de produtos e serviços, dentre outras práticas abusivas: (lista exemplificativa de XII incisos)"

"At "Art 31. A oferta eapresencação de pradutos ou serviços devem assegurar informaçôes conetas, claras, precisas, ostensizas eem língua portuguesa solve suas características, qualidade, quantidade, composiçäo, preço, garantia, prazo de validadee origem, entre outros dados, bem como sobre os riscos quie apresentam á saúde e segurança dos consumidores."

65 "Ant 35. Se ofomecedor de produtos ou serviços recusar cumprimento à oferta, apmesentasáa ou publicidade, o constumidor poderá, alternativamente è sua livre escolha:

I - exigir o cumprimento forçado da obrigação, nos termos da oferta, apresentação ou publicidade; II -. aceitar outro produto ou prestação de serviço equivalente;

III - rescindir o contrato, com direito à restituição de quantia eventualmente antecipada, monetariamente atualizada, e perdas e danos."

66. "Art. 46. Os contratos que regulam as relações de consumo não obrigarão os consumidores, se não lbes for dada a oportunidade de tomar conhecimento prévio de seu conterido, ou se os respectivos instrumentos forem redigidos de modo a dificultar a compreensão de seu sentido e alcance."

"Art. 54. Contratos de adesão é aquele cuja cláusulas tenhan sido aprovadas pela autoridade competente ou estabelecidas unilateralmente pelo fornecedor de produtos ou serviços, sem que o consumidor possa discutir ou modificar substancialmente seu conteúdo.

(...) $\$ 2^{\circ}$. No contratos de adesão, admite-se clátusula resolutória, desde que alternativa, cabendo a escolha ao consumidor (...)".

67 "Art. 51. São nulas de pleno direito, entre outras, as clátsulas contratuais relativas ao fornecimento deprodutos eserviços que: (lista exemplificativa de 16 incisos, senćo um deles vetado ma promulgação da lei)." 
A lei paraguaia de proteção ao consumidor datâ do ano de 1998: Ley 1.334/98 de Defensa del Consumidory del Usuário. A referência à vulnerabilidade não é expressa. Contudo está presente no artigo que determina a interpretação mais favorável ao consumidor: "Art. 27. Las cláusulas contractuales serán interpretadas de la manera más favorable al consumidor." Jáo conceito de consumidor segue os parâmettos das leis Argentina e Brasileira, no sentido de que pessoas jurídicas são incluídas, mas apenas enquanto destinatárias finais, assim como as pessoas físicas: "Art. 4". A los efectos de la presenteley, se entenderán por: a) Consumidor y usuario: a toda persona física ojurídica, naciondlo extranjera que adquiera, utilice o disfrute como destinatario final de bienes o servicios de cualquier naturaleza; ... '. Estão de fora, igualmente, os terceiros envolvidos na relação de consumo.

Com relação à vulnerabilidade técnica, não há menção à publicidade com função de oferta de forma expressa, assin como não se refete expressamente o dever de informação. Há, porém, proibição à publicidade enganosa ou abusiva nos artigos 35 e $37^{6 \%}$, assim como proibição às práticas abusivas na fase pré-contratual (art. 14 $4^{69}$ ). A vulnerabilidade jurídica está protegida através de deveres de transparência (artigos 15 e $8^{077}$, assim como através de determinados requisitos para a possibilidade de revogação da proposta. Já a vulnerabilidade fática ou econômica está protegida através da regulação das condições gerais e previsão de contratos de adesão, havendo referência inclusive aos contratos de timesharing. No art. $28^{71}$, por fim, há uma lista de cláusulas abusivas, porém não há menção se a lista é exemplificativá ou taxativa.

64 "A rt. 35. Está probibida cual quier publicidad considerada engañosa. Se entenderá por tal cualquier modalidad de información, difusión o comunicación de carácter publicitario que sea entera o parcialmente falsa, o que de cualquier otro modo, incluso por omisión, sea capaz de inducir a error al consumidor, cuando se proporcionen datos respecto ala naturaleza, caracteristicas, calidad, cantidad, propictades, origen, precio, condiciones de comercialización, técnicas de producción o cualquier otro dato que sea necesario para definir la relación de consumo."

"Art. 37. Queda prohibida la publicidad abusiva, entendida como aquélla de carácter discriminatorio de cualquier raturaleza, o que aproveche de la falta de madurez de los nitos, infrinja valores medioambientales o sea capaz de inducir al consumidor a comportarse en forma prejudicial o peligrosa para su satud o seguridad."

(6) "Art. 14. Quedaprobibido al proweedor:

a) condjcionar la adquisición de un producto o servicio a la de otro producto o servicio, excepto curando por los usos o costumbres o la naturaleza del producto o servicio, éstos sean ofrecidos en conjunto."

31) "Art. 8"....)

La oferta y presentación de los productos o servicios asegurazá informaciones correctas, claras, precisas $y$ visibles, escritas en idiona oficial, sobre sus caracteristicas, cualidades, cantidad, composición, precio, garantia, plazo de validez, origen, dirección del local de redamo y los riesgos que presenten para la seguridad de los consumidores, en su caso."

"Ant. 15. Salvo porla naturaleza del servicio no se requiera, el proveedor de servicio deberáasegurar en forma dara, comecta yprecisa, las seguintes informaciones: (lisca de 9 itens)."

${ }_{71}$ "Art. 28. Se consideran abusivas y conllevan la nulidad de pleno derecho y, por lo tanto, sin que se puedan oponer al consumidor las clátsulas o estipulaciones que: (lista de 8 itens)." 
A lei uruguaia, última dentre os países do Mercosul a ser aprovada, quase uma década depois do Brasil, em 1999, apresenta a seguinte denominação: Ley 17.189-Dictanse normas relativas a las relaciones de consumo. Ao contrário das demais leis do Mercosul de ptoteção ao consumidor, não há qualquer menção à interpretação favor consumidor na lei uruguaia. Porém há uma regra muito semelhante no que se refere às informaçôes constantes na oferta: "Cuando en la ofertase dienen dos o más informaciones contradictorias, prezdlecerála más fazorable al consumidor". O conceito de consumidor equipara-se ao adotado pela legislação dos demais paises: "Art. ${ }^{\circ}$. Consumidores toda persona física o jurídica que adquirío utiliza productos o servicios como destinatario final enuna relación de consumo o en función de ella. No se considera consumidor ousuario a aquel que, sin constituirseen destinatario final, adquiere, almacena, utiliza o consume productos o servicios con el fin de integrarlos en procesos de producción, transformación o comercialización. "Portanto, incluiu as pessoas jurídicas e, inclusive, fez ressalva expressa quanto aos destinatários finais.

Com relação vulnerabilidade técnica, a lei uruguaia a protegeu através de regras sobre a publicidade com função de oferta (artigos 12 e $14^{7 / 2}$ ), embora nada mencione expressamente sobre o dever de informar. Há também proibição com relação à publicidade enganosa (art. $24^{73}$ ), e menção à prova da veracidade da oferta (art. $26^{74}$ ). Também há proibição às práticas contratuais abusivas na fase pré-contratual (art. $22^{75}$ ). A vulnerabilidade jurídica está protegida através de deveres de transparência (artigos $12,17,8^{\circ}$ e $\left.13^{76}\right)$. Prevê-se a revogação da proposta, caso cumpridos certos requisitos (art. 12). Quanto à vulnerabilidade fática ou

72 "Art 12. La fertadirigida a consumidones determinados o indeterminados, transmitida por cualquiermedio de comunicación y que contenga información sufucientemente precisa con relación a losproductos o servicios of recidos, vinala a quien la emite y aquel que la utiliza de manera expresa por el tiempo que se realice. (...)"

"Axt. 14. Toda información, aun la proporcionada en avisos publicitarios, difundidos pro cualquier forma medio de comunicación, obliga al oferente que ordenó su difusión y a todo aquel que la utilice e integra el contrato que se celebre con el consunidor."

13 "Art. 24. (...) Queda probibida cualquier publicidad engañosa.

Se entenderá por publicidad engañosa cualçuier modalidad de información o comunicación contenida en mensajes publicitarios que sea entera o parcialmente falsa, o de cualquier otro modo, incluso por omisión de datos esenciales, sea capaz de inducir a error al consumidor respecto a la naturaleza, cantidad, origen, precio, respecto de los productos y servicios."

${ }_{74}$ "Art. 26. La carga de la prueba de la veracidad y exactud material de los datos de becho contenidos en la información o comunicación publicitaria, corresponde al anunciante."

75 "Art. 22. Son consideradas prácticas abusivas, entre otras: (lista de 5 itens)." Vale referir que encontra-se o referido artigo no Capírulo VII, entitulado: "Prácticas abusivas en la Oferta".

${ }^{76}$ "Ant. $8^{\circ}$. Los proveedores de productos y servicios peligrosos o nocivos para la saludo seguridad deberán informar en forma clara y visible sobre su peligrosidad o nocividad, sin perjuicio de otras medidas que puedan comarse en cada caso concreto." "Art. 17. La oferta de productos debe brindar información clara y fácilmente legible sobre sus caracteristicas, naturaleza, cantidad, calidad - en los términos y oportunidades que correspondan composición, garantía, origen del producto, el precio de acuerdo a lo establecido en el artículo 15, los datos necesarios para la correcta conservación y utilización del producto y, según corresponda, el plazo de validez y los riegos que presente para la salud y seguridad de los consunidores.(...)". 
econômica, a lei prevê condições gerais de contratação e contratos de adesão (artigos $28 \mathrm{e}$ $29^{77}$ ). Nos artigos $30^{78}$ e 31, há uma lista de cláusulas abusivas, que violam os direitos dos consumidores e a boa-fé. A lista do $31^{79}$ é exemplificativa.

B) Os Acordos Regionais, a Noção de Vulnerabiljdade e a Proteção da Parte da mais Fraca no Mercosul.

Analisando o desenvolvinento do Direito Internacional Privado ${ }^{80}$ no Mercosul, ARROYO ${ }^{81}$ menciona que, desde o princípio, o Mercosul excursionou por vários terrenos do Direito Internacional Privado: solução de controvérsias (Protocolo de Brasillia - 1991 ${ }^{22}$ ); reconhecimento e execução de decisões com auxilio judicial internacional (Protocolo de Las Leñas sobte Cooperação e Assistência Jurisdicional em matéria Civil, Comercial, Trabalhista e Administrativa - 1992 ${ }^{83}$ ); competência judicial internacional em matéria contratual (Protocolo de Buenos Aires sobre Jurisdição Internacional em Matéria Contratual - 1994 ${ }^{84}$ ) e Medidas Cautelares (Protocolo de Outro Preto sobre Medidas Cautelares - $1994^{85}$ ); responsabilidade civil emergente de acidentes de trânsito entre os Estados do Mercosul (Protocolo de São Luiz -19968) e, finalmente, o Protocolo de Santa Maria, também em 1996, que especialmente nos interessa, sobre jurisdição internacional em matéria de relações de consumo, complementando o Prorocolo de Buenos Aires. Vê-se, pois, que a codificação de matćrias de DIPr foi intensa e variada, ocupando-se de setores materiais do DIPr, assim como da parte geral e especial do DIPr clássico. De fato, embora o Mercosul ainda não possua base jurídica sólida, já atua e legisia ${ }^{87}$.

"7" "Art. 28. Contrato de adhesión es aquel cayas cláusulas o condiciones han sido establecidas unilateralmente por el proveedor" de productos o servicios sin que el consumidor hatya podido discutiv, negaciar o madificar sustancialmente su contenido. (...)". "Art, 29. Los contratos de adhesión serán redactados en idioma español, en términos claros y con caracteres fácilmente legibies, de moco tal que faciliten la comprensión por el consumidor".

78 "Ant 30. Es abusiva Por su contenido opor su foma, toda cláusula que deternine claros e injustificados desequilibrios entre los derechos yobligaciones de los contratantes en perjuicio de los consumidores, así como toda aquella que viola la obligación del carácter abusizo de las cláusulas no referivá al produt to o servicio nial precio o contraprestación del contrato, siempre que dichas cláusulas se redacten de manera claray comprensible."

${ }^{79}$ "Art. 31. Son consideras cláusulas abusivas, sin prejuicio de otras, las siguientes: (isca de 8 itens)."

8tit Utiliza-se a sigla DIPr.

81 ARROYO, Diego P. Fernández. La nueva configuración del Derecho Internacional Privado del MERCOSUR: ocho respuestas contra fa incertidumbre. Revista de Direito do Mercosul, a. 3, n. 4, ago. 1999, p. $38-53$, P. $40 / 1$.

${ }^{2}$ No Brasil, Decreto 922 , de $10 / 09 / 1993$.

83 No Brasil, Decreto 2.067 , de $12 / 11 / 1996$.

${ }^{84}$ No Brasil, Decreto 2.095, de 17/12/1996.

${ }^{85}$ No Brasil, Decreto 2.626 , de $15 / 06 / 1998$.

86 No Brasil, Decreto 3.856 , de 03/07/2001.

${ }^{87}$ MARQUES, Cládia Lima. O "Direiro do Mercosul": Direito oriundo do Mercosul, entre Direito Internacional Clássico e Novos Caminhos de Integração. Derecho Del Mercosur y la Integración, n. 1, feb./ 2003, p. $61=89$, p. 64 . 
Vale, então, realizar uma retrospectiva acerca da proteção do consumidor no Mercosul, em nivel regional, desde o Tratado de Assunção, em 1990. Tal como afirma Newton de LUCCA ${ }^{86}$, embora tenha havido expressa alusão no considerando do Tratado de Assunção à preservação do meio ambiente e à melhoria das condições de vida do consumidor, tais objetivos não foram transformadas em medidas de caráter concreto. Sem dúvida, um dos motivos foi a ausência de um sistema eficaz de solução de controvérsias que, sem dúvida, teria ajudado em muito no processo de integração como um todo ${ }^{89}$. Conforme ARRIGHI' na Europa, ante um panorama quase tão árido como o presente no Mercosul, foi obra da jurisprudência comunitária, a partir do caso célebre "Cassi-de-Dijon", a proteção ao consumidor. Infelizmente o tratado constitutivo do Mercosul não previa uma forma de solução de controvérsias. Essa ausência ao longo de todo o processo de integração - que quase completam 15 anos - foi certamente muito prejudicial para todo o desenvolvimento do bloco, assim como para a proteção do consumidor.

Também LUCCA $A^{\text {11 }}$ nos mostra, contudo, que a primeira vez em que se aludiu ao consumidor no âmbito do Mercosul ocorreu na X Reunião do Grupo Mercado Comum do Mercosul, realizada entre os dias 28 a 30 de junho de 1993, no item A4 da respectiva ata, recomendando ao Subgrupo de Trabalho $\mathrm{n}^{\circ} 10$ que elaborasse diretrizes para a respectiva comissão, no sentido de uma política de defesa do consumidor. Deve-se mencionar que a inclusão da defesa da defesa do consumidor como tema importante no Mercosul foi uma sugestão do governo brasileiro, conscientizado da posição estratégica do tema e de sua intima relação com a concorrência leal nos mercados internos ${ }^{32}$.

Em notas esclarecedoras sobre a evolução da proteção do consumidor no Mercosul, Cláudia Lima MARQUES"3. refere que o consumidor, de "agente esquecido" passou a foco de um trabalho consciente e tópico pela Reunião de Ministros de Justiça do Mercosul. A partir de 1993, então, iniciou-se um grupo de trabalhos. Em 1994, foi elaborada uma tesolução, definindo a chamada regra de origem como reguladora da questão consumeirista no Mercosul. De fato, a grande questão que se colocava, a partir de 1993, eri o estabelecimento de padrões mínimos de proteção, favorecendo ou não a venda. O Brasil já apresentava um rígido código de proteção ao consumidor, enquanto outros países ainda não haviam se desenvolvido

${ }^{58}$ LUCCA, O Mercostul, p. 10.

: LUCCA, O Mercosul, p. 11/2. Também mostrando preocupação com a ausência de um sistema eficiente de solução de controvérsias no Mercosul: ARROYO, Diego P. Femández. La Nueva, p. 40 e MARQUES, O Código de Defesa do Consumidor e o Mercosul. RDC, n. 8, out./dez. 1993, p. 40-57, p. 41.

"ARRIGHI, La Protección, p. 13.

"LUCCA, O Mercosul, p. 13. No mesmo sentido, MARQUES, O Código, p. 54 e MARQUES, MARQUES, Cláudia Lima, Direitos do consumidor no Mercosul: algumas sugestões frente ao impasse. $R D C$, n. 32 , out./dez. 1999, p. 16-44, p. 32, p. 20.

${ }^{92}$ MARQUES, Direitos, p. 26.

${ }^{25}$ Id., ibid., p. 21/2. 
neste sentido: Não há qualquer dúvida que o CDC impunha, como ainda impõe, um novo padrão de conduta por parte dos fornecedores do bloco. Contudo não se pode afirmar que o CDC impedisse a entrada de um produto ou serviço. Por isso, não podia o Código ser considerado barreira, por não especificar quem podia prestar serviços no mercado brasileiro ou quais os produtos que podiam ser comercializados, mas sim responsabilidades e deveres de informação e indenização. ${ }^{95}$. Nessa época, como ainda hoje, vigorava a tegra do estado de origem: se para o Estado de origem o produto possuísse a qualidade e a segurança exigidas, isso bastaria, não sendo possível aplicar-se a tegra do país de comercialização, porque estaria dificultando seu acesso ao novo mercado ${ }^{96}$.

Em 1996, passa-se à nova fase, quando o consumidor volta ser tema polêmico na Comissão de Comércio do Mercosul. Passou-se a elaborar um corpo de normas completo sobre o tema para os quatro países, dando origem ao Prorocolo Comum, em 199797. Ao longo do processo de integração, esse Protocolo representou um momento de grave crise no que respeita a proteção do consumidor no bloco, já que estabelecia padrões de proteção ao consumidor mais baixos do que os presentes na Lei Brasileira. Lembre-se que à época o Paraguai e o Uruguai ainda não haviam aprovado suas leis. Tal Protocolo não harmonizaria as referidas leis, mas, sim, unificaria a proteção do consumidor no Mercosul ${ }^{98}$, substituindo as leis protetivas internas.

Embora não tenha sido aprovado, o Protocolo Comum trouxe como resultado negativo a falta de vigência efetiva do Protocolo de Santa Maria, que realmente protege o consumidor regional. Ocorre que o de Santa Maria somente entratia em vigor após encerrados os trabalhos de unificação da Comissão de Comércio do Mercosul (art. $18^{\%}$ ), o que nunca ocorreu, permanecendo em um chamado limbo jurídico. Contudo, não se deve desconsiderálo como legislação do bloco, regulando a jurisdição internacional em matéria de consumo. Conforme aponta a douttina, o teferido Protocolo veio a complementar o Protocolo de Buenos Aires, acerca da competência em caso de contratos internacionass, já que determina foro privilegiado ao consumidor, assim como the facilita o reconhecimento de sentenças e $O$

\footnotetext{
${ }^{34}$ MARQUES, O Código, p. 42.

${ }^{4}$ MARQUES, O Código, p. 51 e MARQUES, Los Derechos del Consumidor. Uma Visión Comparativa entre el Brasil y la Argentina. In: GHERSI, Carlos A. (Org.). MER COSUR - Perspectivas desde el Derecho Privado Parte segunda. Buenos Aires: Bditorial Universidad, 1996, p. 217/8.

${ }^{16}$ MARQUES, O Código, p. 52. e MARQUES, Los Derechos, p. 216.

${ }^{27}$ O referido Protocolo encontra-se publicado na Revista de Direito do Consumidor, números 23-27, p. 518/531. Juntamente ao Protocolo encontra-se publicada a Ata da Reunião que recusou o Projeto de Protocolo, p. 533-535.

${ }^{98}$ Neste sentido, DE LUCCA, O Mercostal, p. 16.

"y "A tramitação da aprovaação do presente Protocolo no âmbito de cada uim dos Estados Partes, com as adequaçóes que forem necessárias somente terá início após a aprovação do 'Regulamento Cmum MER COSUL de Defesa do Consumidor'em sua totalidade, inclusive eventuais anexos, pelo Conselbodo Mercado Comum."
} 
juizo à distância. Refere ARROYO ${ }^{100}$ que a autonomia da vontade ${ }^{109}$ é pedra angular para a solução dos litígios relativos aos contratos firmados no Mercosul, a partir do Protocolo de Buenos Aires. Contudo não a permite quanto aos contratos concluídos com consumidores (art. $2^{\circ}, 6$ ), contratos de seguros $\left(\operatorname{art} 2^{\circ}, 8\right.$ ), contratos de transporte (art. $2^{\circ}, 7$ ) e problemas de direito real (art. $\left.2^{\circ}, 9\right)^{112}$. O consumidor é conceituado no Protocolo de Santa Maria como o destinatário final de bens e serviços de utilização familiar, a exemplo da lei argentina. Deixa, portanto, de fora do conceito rodos aqueles os que a lei brasileira inclui, diferentemente dos demais paises do Mercosul (art. $2^{\circ}, 17$ e 29 do CDC) ${ }^{103}$.

Vale referir que a limitação da autonomia da vontade não é a única forma de proteger o consumidor na contratação internacional. As normas de jurisdição modemamente também costumam brindar-lhes foros de jurisdição acessiveis, como os de sua própria residência, além de permitir-lhes demandar ante os juízes da sede a empresa ${ }^{104}$. A fórmula central não parece passar por evitar a auronomia da vontade absolutamente, mas impedir que a eleição de um direito leve à nâo aplicação das normas imperativas que caberiam se houvesse eleição. As normas indiretas aplicáveis podem levar (orientar) materialmente à proteção do consumidor ${ }^{\text {t015 }}$.

Analisando a proteção internacional do consumidor, o autor argentino TONIOLLO ${ }^{1 \text { 1sr }}$ sugete um conceito amplo de consumidor, assim como a criação de possibilidades de conexões ao consumidor, que escolherá aquela que lhe for mais favorável. Para o autor ${ }^{30 \%}$, é preciso partir sempre da residência habitual do consumidor, obrigando o fornecedor-parte forte da relação - a conhecer as normas protetoras dos lugares onde normalmente se produzem os atos de consumo, destino final dos bens e serviços. Também deve ser oferecida ao consumidor a possibilidade de optar pela lei do estabelecimento principal ou residência do provedor ${ }^{108}$. Quanto ao lugar de celebração do contrato (lex loci celebracionis - conexão hoje ainda adotada

${ }^{109}$ ARROYO, La nueva, p. 41.

101 Acerca da altonomia da vontade como regra de conexäo dos contratos internacionajs pela América Latina, menciona-se o Curso de Haia de Boggiano (BOGGIANO, Antonio. The Contribution of the Hague Conference to the Development of Private International Law in Lain America - Universality and genus loci. Recueil des Cours, 1992, II, tome 233, p. 103-266) e o livro de Nádia de Araújo (ARAÚJO, Nádia de. Contratos Internacionais - autonomia da wontade, Mercosule convenções internacionais. 3 ed., Rio de Janeiro, São Paulo e Recife: Renovar, 2004). Nào será discutida a autonomia da vontade nos contratos internacionais no presente trabalho, apenas no que tangenciar a questão de defesa dos vulnetáveis.

102 MARQUES, Direitos, p. 32.

${ }^{103}$ Id., ibid., p. 34.

${ }^{104}$ ARROYO et al, Modalidades Contractuales, p. 1032. No mesmo sentido, TONIOLLO, Javier Alberto. La Protección Internacional del Consumidor - Reflexiones desde la perspectiva del Derecho Internacionat Privado Argentino. Revista de Direito do Mercosul, a. 2, n. 6, dez. 1998, p. 94-118, p. 96.

${ }^{105}$ ARROYO et al, Modalidades Contractuales, p. 1035.

106 TONIOLLO, La Protección, p. 113.

${ }^{107}$ Id., ibid., p. 102.

${ }^{103}$ Id., ibid, p. 100. 
pela Lei de Introdução ao Código Civil Brasileira $\left.{ }^{10^{*}}\right)$, o autor crề que essa conexão perde espaço para a do lugar de aquisição do produto, a não ser que se criasse uma regra que unisse as duas conexões: o lugar de aquisição do produto, quando coincida com o lugar de celebração, e seja possível identificar-se este último. Assim, também o direito do lugar de celebração, interpretado como o lugar de aquisição, deveria constituir uma faculdade do consumidor. Ressalte-se, porém, que o lugar do efetivo cumprimento se sobressai ao lugar de celebração, por favorecer mais consumidor ${ }^{110}$.

Com relação, portanto, à autonomia da vontade, a proposta de TONIOLLO é mantêla também com relação ao consumidor, porém a partir de determinados limites, isto é, o consumidor opta dentre as soluções aquela que the seja mais favorável. Essa solução não deve deixar de fora os limites comumente aplicados à autonomia, como a Ordem pública e as normas de polícia ${ }^{11}$. Para o autor em discussão, pois, a opção de excluir a autonomia conta com mais inconvenientes do que vantagens, pois não resolve o desequilíbrio.

Com xelação aos acidentes de consumo, sugere o autor que primeiramente se considere a tesidência habitual daquele que sofreu o dano, se coincidente com a lex lociactus (que é a conexão clássica adotada pelo Tratado de Montevidéu, 1940, art. 43). Em segundo lugar, à escolha do consumidor, pode-se deteminar como solução o local do estabelecimento principal da pessoa que se pretenda responsabilizar ou o lugar de aquisição do produto. Independentemente, então, da dicotomia responsabilidade contratual ou extracontratual, a solução deveria ser a mesma. Sempre, é claro, sem deixar de lado a Ordem Pública c as normas de polícia do foro do juiz $z^{112}$.

Conforme se constata, então, o Mercosul ainda carece de soluções efetivas para a proteção regional do consumidot. A única norma de caráter realmente protetivo adota um conceito limitado de consumidor, assim como se encontra em uma situação de indefinição legislativa. Resta, portanto, apresentar as soluções da doutrina do Mercosul, conforme muito bem exposto por Toniollo, no sentido de se adotar regras de DIPr para a proteção do consumidor, ao contrário do criticado Protocolo Comum de 1997, que buscou uma negativa unificação,

\footnotetext{
109 Artigo $9^{\circ}$ da Lei de Introdução ao Código Civil - Brassil.

"10 TONIOLLO, La Protección, p. 102.

"1] I., ibid., p. 103.

112 1 d., ibid., p. 111/2.
} 


\section{CONCLUSÃO}

Viu-se que a concepção de vulnerabilidade não é nova no Direito. A adoção de formas de proteção dos sujeitos mais fracos não constitui revolução, apenas uma evolução ou continuidade da necessidade do Direito ou dos juristas - como menciona a frase inicial deste trabalho - de se adequarem ao seu tempo. Dessa forma, não causa espécie todos os países do Mercosul apresentarem leis de defesa do consumidor com padrões mínimos de proteção equânimes. Isso se deve, em muito, a esse caráter universal de vulnerabilidade, pois, conforme apontou a doutrinária analisada, todos vêem a vulnerabilidade da mesma maneira, isto é, embora nem todos explicitem, todos compreendem que é a informação o critério que determina a posição mais forte ou mais fraca do indivíduo na relação contratual de massas. Contudo, já se evoluiu a tal ponto que esse caráter protetivo é estendido aos terceiros envolvidos nessa relação, os chamados bystanders. E aí a beleza das palavras de Lorenzetti, ao afirmar que se evolui do favor debitoris para a proteção do individuo enquanto pessoa.

Nesse sentido, deve ser ressaltado e enobrecido o papel das Nações Unidas na adoção pelos países do sul da América Latina de leis protetivas, assim como o papel das Constituições democráticas adotadas nesses países na década de 80 . Sem dúvida, por constituir direito de nova geração, a defesa do consumidor não seria albergada nesses países sem a volta da democracia. De fato, nem todos os países do Mercosul elevaram o consumidor à mesma categoria, seja na Constituição ou na amplitude do conceito de consumidor em suas leis. Contudo - e a influência dos demais países do bloco foi fundamental, destacando-se o papel líder do Brasil - todos acabaram o século XX com suas leis de proteção ao consumidor. Em nivel regional, sabe-se que o sucesso do Mercosul enquanto processo de integração não foi o esperado. E o direito do consumidor experimentou um dos lados mais negativos desse processo, quando houve a tentativa de diminuir a proteção no Brasil, aprovando-se um Protocolo para todos os países do bloco. Felizmente, o grau de organização da sociedade brasileira - nesse sentido o importante papel da Universidade e do Ministério Público impediu os efeitos negativos da integração. Efetivamente, o Mercosul ainda adora a regra da origem, determinando que o grau de proteção exigido no país de origem do produto seja suficiente. Hoje, já que todos paises apresentam leis de proreção, essa regra não é de todo ineficiente, embora padrões mais altos de proteção certannente já poderiam ter sido obtidos ${ }^{113}$. Assim, excetuando-se o Protocolo Comum rejeitado em 1997, pode ser considerada regra de proteção ao consumidor no Mercosul o Protocolo de Santa Maria, que estabelece foro privilegiado e à sua escolha para o consumidor, complementando o Protoco de Buenos Aires que regula as relações contratuais.

11. Nesse sentido, MARQULS, Direitos, 34/5. 
Enfim, um longo caminho ainda há. Não se pode negar, contudo, que os países do Mercosul já evoluíram juridicamente de forma bastante positiva desde a democratização na década de 80. Cita-se, concluindo-se, uma frase de Pontes de Miranda, que embora não tenha vivido o auge do movimento consumeirista no Brasil, compreendeu bem o seu tempo e o caráter universal e sucial do homern, que é justamente o que demonstra a sua vulnetabilidade: "o social precede necessariamente o bomem, porque não foi o bomem que fez a assembléia, odiálogo; foi a assembléta, odiálogo, quefezobomem." 


\section{BIBLIOGRAFIA}

ALTERINI, Atílio Aníbal. Os Contratos de Consumo e as Cláusulas Abusivas. RDC, n. 15, jul./set. 1995 , p. 5-19.

Tendencias en la Contratación Moderna. RDC, n. 31, jul./set., 1999, p. 104-114.

ARAUjO, Nádia de. Contratos Internacionais - autonomia da vontade, Mercosul e convenções internacionais. 3 ed., Rio de Janeiro, São Paulo e Recife: Renovar, 2004.

ARRIGHI, Jean Michel. La Protección de los Consumidores y el Mercosur. RDC, n. 1, mar. 1992, p. 124-136.

AIRROYO, Diego P. Fernández Arroyo (coord.). Derecho Internacional Privado de los Estados del MERCOSUR - Argentina, Brasil, Urugudy e Paraguay. Buenos Aires: Zavalia, 2003.

La nueva configuración del Derecho Internacional Privado del MERCOSUR: ocho tespuestas contra la incertidumbre. Revista de Direito do Mercosul, a. 3, n. 4, ago. 1999, p. 38-53.

BATISTI, Leonir.Direito do Consumidorpara o Mercosul-enfoque jurídico eeconômico dos Blocos de Integração. Curitiba: Juruá, 1998.

BENJAMIN, Antônio Hermam Vasconcelos et al. Código Brasileiro de Defesa do Consumidor comentado pelos autores do Anteprojeto. Rio de Janeiro: Forense Universitátia, 1995.

BOGGIANO, Antonio. The Contribution of the Hague Conference to the Development of Private International Law in Latin Anerica - Universality and genus loci. Recueil des Cours, 1992, II, tome 233, p. 103-266.

CABANA, Roberto M. Lopez. Defensa Jurídica de los más débiles, RDC, n. 28, out./dez. 1998, p. 7-21, p. 7.

CASTILLA, Gustavo Ordoqui. Deber de Información em la Ley 17.189 , de 20 de Setiembre de 1999. $R D C$, n. 34, a. 9, abril-jun./2000, p. 45-77.

ESPANÉS, Luis Moisset. TINTI., Guillermo P. Consideraciones sobre el Consumo e el Derecho del Consumidor. Rev. Faculdad de Derecho y Ciencias Sociales - Universidad Catolica de Córdoba, tomo II, ano 1999, p. 85-100.

FEKETE, Elisaberh Kasznar. A Proteção do Consumidor como Instrumento de A perfeiçoamento da Integração Econômica no Mercosul -- com especial relevo para o relacionamento com o diretio das marcas e da concorrência desleal. $R D C$, n. 20 , out./ dez. 1996, p. 112-126.

GHERSI, Carlos A. (Org.).MERCOSUR-Perspectizas desde el Derecho Privado-Parte segunda. Buenos Aires: Editorial Universidad, 1996. 
ITURRASPE, Jorge Mosset. Las Cláusulas Abusivas em la Contratación (informe del derecho argentino), RDC, n. 44, out./dez. 2002, p. 49-67.

LUCCA, Newton de. O Mercosul $e$ a defesa dos consumidores brasileiros. Revista de Direito do Mercosul.a. 2, n.5, out. 1998, p. 5-11.

MARQUES, Cláudia Lima. Contratos no Código de Defesa do Consumidor, 4 ed., São Paulo: Revista dos Tribunais, 2002.

O Código de Defesa do Consumidor e o Mercosul. $R D C$, n. 8, out./dez.1993, p. $40-57$.

Los Derechos del Consumidor. Uma Visión Comparativa entre el Brasil y la Argentina. In: GHERSI, Carlos A. (Org). MER COSUR - Perspectivas desde el Derecho Privado-Parte segunda. Buenos Aires: Editorial Universidad, 1996.

Direitos do consumidor no Mercosul: algumas sugestões frente ao impasse. RDC, n. 32, out./dez. 1999, p. 16-44.

O "Direito do Mercosul": Direito oriundo do Mercosul, entre Direito Intennacional Clássico e Novos Caminhos de Integração. Derecho Del Mercosury la Integración, n. 1, feb./ 2003, p. $61-89$.

MORAES, Paulo Valério Código de Defesa do Consumidor - o princípio da vulnerabilidade no contrato, napublicidade enas demais práticas comerciais. Porto Alegre: Sintese, 1999.

RAMÍREZ, Patrício Carvajal. Sugerencias para um Derecho de Consumo Unitário. Revista Chilena de Derecho, v. 29, n., 1, enero/abril 2002, p. 127/137.

SOSSO, Gonzalo. Daños Derivados Del Acto de Consumo. RDC, n. 35, abr./jun. 2000, p. 9-33.

STIGLITZ, Gabriel. O Direito Contratual e a Proteção Jurídica do Consumidor. $R D C, \mathrm{n} .1$, mar. 1992, p. 184-200.

- O Direito do Consumidor e as Práticas Abusivas - realidade e perspectiva na Argentina. RDC, n. 3, set./dez, 1992, p. 27-35.

TADEU, Silney Alves. O Consumidor como Categoria Especial $\rightarrow$ uma perpectiva comunitátia, RDC, n. 47, jul./set. 2003, p. 180-199.

TONIOLLO, Javier Aiberto. La Protección Internacional del Consumidor - Reflexiones desde la perspectiva del Derecho Internacional Privado Argentino. Revista de Direito do Mercosul, a. 2, n. 6, dez. 1998, p. 94-118. 